\title{
Symposium review: Nutrition strategies for improved health, production, and fertility during the transition period*
}

\author{
F. C. Cardoso, ${ }^{1} \dagger$ 자. K. F. Kalscheur, ${ }^{2}$ () and J. K. Drackley ${ }^{1}$ (1) \\ ${ }^{1}$ Department of Animal Sciences, University of Illinois, Urbana 61801 \\ ${ }^{2}$ US Dairy Forage Research Center, Agricultural Research Service-USDA, Madison, WI 53706
}

\begin{abstract}
Dairy cow nutritional programs are a major determinant of the profitability of dairy farms. Despite this, the sustainability of the dairy enterprise is beyond just cow nutrition. For almost $50 \mathrm{yr}$, the NC-2042 project (Management Systems to Improve the Economic and Environmental Sustainability of Dairy Enterprises) has been addressing most of these components as individual research units and in integrated ways. This review has the objective to report the body of research developed by members of the group in connection with the existing literature on dietary formulation and feeding management during the dry period, peripartal period, and early postpartum (fresh) period. Peak disease incidence (shortly after parturition) corresponds with the time of greatest negative energy balance (NEB), the peak in blood concentrations of nonesterified fatty acids, and the greatest acceleration of milk yield. Decreased fertility in the face of increasing milk production may be attributable to greater severity of postpartal NEB resulting from inadequate transition management or increased rates of disease. The depth and duration of NEB is highly related to dry matter intake. Periparturient diseases can result from adverse ruminal conditions caused by excessive grain in the precalving or fresh cow diet, perhaps aggravated by overcrowding, heat stress, or other stressors. Others have also implicated inflammatory responses in alterations of metabolism, occurrence of health problems, and impaired reproduction. Providing controlled-energy and negative dietary cation-anion difference diets prepartum may improve dairy cow performance during the transition period. A major area of concern in the fresh cow period is a sudden increase in dietary energy density leading to subacute ruminal acidosis, which can decrease dry
\end{abstract}

Received July 15, 2019.

Accepted November 23, 2019

*Presented as part of the Production, Management, and the Environment: Profitability and Sustainability Symposium at the ADSA Annual Meeting, Cincinnati, Ohio, June 2019.

†Corresponding author: cardoso2@illinois.edu matter intake and digestibility of nutrients. Adequate physical form of the diet, derived from either forage neutral detergent fiber content or a mixing strategy of different ingredients in a total mixed ration, must be present to stimulate ruminal activity and chewing behavior. In conclusion, formulation and delivery of appropriate diets that limit total energy intake to requirements but also provide proper intakes of all other nutrients (including the most limiting amino acids Met and Lys) before calving can help lessen the extent of NEB after calving. Effects of such diets on indicators of metabolic health are generally positive, suggesting the potential to lessen effects of periparturient disease on fertility.

Key words: dietary cation-anion difference, negative energy balance, amino acid, fertility

\section{INTRODUCTION}

The periparturent period (transition period) is defined in dairy cows as a state of near maintenance requirements in late gestation changing to that of rapidly increasing metabolic and nutrient demands needed for the onset of lactation (Bell, 1995). Decreased dietary energy density during late gestation induces changes in metabolism leading to mobilization of fat from adipose tissue and glycogen from liver. At parturition, the dairy cow is subjected to various challenges that can affect her future lactations and fertility. Failure or inadequate adaptation to these changes can leave the cow predisposed to metabolic disorders such as ketosis, acidosis, and displaced abomasum (Drackley, 1999; Vernon, 2005), infectious disorders such as metritis and mastitis (Sheldon et al., 2002b; Mulligan et al., 2006), or calving-related disorders such as dystocia, retained placenta, and decreased fertility (Roche et al., 2000; Sheldon et al., 2002a).

Controlling energy with high-fiber rations seems to improve DMI after parturition, thereby avoiding excessive adipose tissue lipid mobilization (Douglas et al., 2006). Milk production is similar when compared with higher energy close-up programs (Douglas et al., 2006; 
Janovick and Drackley, 2010; Mann et al., 2015). Additionally, the benefits of the controlled-energy (CE) diet prepartum seems to have a positive effect on cows' fertility (Cardoso et al., 2013). This dietary strategy aims to formulate and feed rations with relatively low energy density (1.30 to $1.39 \mathrm{Mcal}$ of $\mathrm{NE}_{\mathrm{L}} / \mathrm{kg}$ of $\mathrm{DM}$ ) during the entire dry period. The incorporation of lowenergy ingredients (straw or low-quality grass hays) allows cows to consume the diet ad libitum without exceeding their daily energy requirements (Janovick and Drackley, 2010).

What is believed to be an underlying issue in disorders around parturition is an imbalance in Ca homeostasis at the onset of lactation. Calcium, an important macromineral involved in smooth muscle contraction, milk synthesis, and immune cell activation, reaches a nadir in the first days after parturition at the onset of lactation. At the onset of lactation, Ca requirements increase 4-fold to meet the demands of lactogenesis (Horst et al., 1997). Failure to adapt can delay uterine involution, delay return to ovarian cyclic activity, and diminish immune responses (Griffin et al., 1974; Kimura et al., 2006; Sheldon et al., 2006).

An estimated 5 to $10 \%$ of dairy cows experience hypocalcemia (HC; milk fever, parturient paresis) at the time of parturition (Oetzel, 2011), with an estimated cost of $\$ 246$ per case (Liang et al., 2017). The prevalence of subclinical hypocalcemia [SCH; estimated at $33 \%$ of all first lactations or greater (Reinhardt et al., 2011)] is considerably higher, and consequently, its economic impact is more significant than HC. Subclinical hypocalcemia is often undiagnosed and primes the cow for other disorders in addition to decreased milk production (Horst et al., 1997; Goff, 2008).

One dry cow nutritional management practice used to decrease the incidence of $\mathrm{HC}$ is to feed an acidogenic or partially acidogenic diet to cows entering the close-up period up until parturition. This is achieved by manipulating the DCAD. Acidification of the diet is realized when the concentration of anions is greater than that of the concentration of cations. This increases anion absorption in circulating blood and leaves the cow in a slight state of metabolic acidosis. Various studies (Charbonneau et al., 2006; Santos et al., 2019) have reported that this practice decreases the chances of the cow developing $\mathrm{HC}$ and $\mathrm{SCH}$. The mechanisms of action include maintaining parathyroid hormone sensitivity to $\mathrm{Ca}$ homeostasis and increasing calciotropic receptor numbers (DeGaris and Lean, 2008). Feeding a negative DCAD diet prepartum (fully or partially acidified) increased the subsequent reproductive performance as well as improving the $\mathrm{Ca}$ status of the cow (Chapinal et al., 2012; Martinez et al., 2018; Ryan et al., 2020).
Methionine and Lys are the most limiting AA in lactating cows (NRC, 2001), but supplementation of diets with crystalline Met and Lys has been excluded because both are quickly and almost totally degraded by the microorganisms in the rumen (NRC, 2001). In contrast, supplementing rumen-protected Met (RPM) and rumen-protected Lys had a positive effect on milk protein synthesis in dairy cows (Ordway et al., 2009; Osorio et al., 2013). Although the role of Met in bovine embryonic development is unknown, evidence indicates that Met availability alters the follicular dynamics of the first dominant follicle (DF; Acosta et al., 2017), the uterine environment (Skenandore et al., 2017; Stella et al., 2018), the transcriptome of bovine preimplantation embryos in vivo (Penagaricano et al., 2013), and the embryonic lipid content (Acosta et al., 2016).

The objectives of this manuscript are to review the body of research developed by members of the NC 2042 and the available literature on dietary strategies during the dry period, peripartal period, and early postpartum (fresh) period, and how they relate to outcomes that influence health, reproduction, and performance of dairy cows. Nutritional strategies are paramount for a successful transition from the nonlactating to lactating period and for improving the health, milk production, and reproduction of the dairy cow.

\section{REPRODUCTION, NUTRITION, AND HEALTH}

A widespread assumption is that fertility of modern dairy cows is decreasing, particularly for Holstein-Friesen genetics, in part because of unintended consequences of continued selection for high milk production (Crowe et al., 2018). This assumption has been challenged recently (LeBlanc, 2010). Reproductive success is widely distributed both within and among herds. For example, within 5 California herds with a total of 6,396 cows, cows in the lowest quartile for milk yield in the first 90 d postpartum $(32.1 \mathrm{~kg} / \mathrm{d})$ were less likely to have resumed estrous cycles by 65 ds postpartum than cows in quartiles $2(39.1 \mathrm{~kg} / \mathrm{d}), 3(43.6 \mathrm{~kg} / \mathrm{d})$, or $4(50.0 \mathrm{~kg} / \mathrm{d})$; milk production did not affect risk for pregnancy (Santos et al., 2009). Nutrient demand for milk synthesis is increased in early lactation. If no compensatory intake of nutrients is achieved to cope with the requirement, reproductive functions (i.e., synthesis and secretion of hormones, follicle ovulation, and embryo development) may be depressed. For instance, Bach et al. (2008) reported that non-nutritional management accounted for more than $50 \%$ of the variation in mean milk production $(20.6$ to $33.8 \mathrm{~kg} / \mathrm{d}$ ) among 47 herds fed exactly the same TMR. Therefore, changes in management systems and inadequacies in management may be more limiting 
for fertility of modern dairy cows than their genetics per se.

Dairy cows are susceptible to production disorders and diseases during the peripartal period and early lactation, including milk fever, ketosis, fatty liver, retained placenta, displaced abomasum, metritis, mastitis, and lameness (Mulligan et al., 2006; Roche et al., 2013). There is little evidence that milk yield contributes to greater disease occurrence. However, peak disease incidence (shortly after parturition) corresponds with the time of greatest negative energy balance (NEB), peak in blood concentrations of nonesterified fatty acids (NEFA), and the greatest rate of increase of milk yield (Drackley, 1999). Peak milk yield occurs several weeks later. Disorders associated with postpartum NEB also are related to impaired reproductive performance, including fatty liver and ketosis (McArt et al., 2012). Cows that lost $>1$ BCS unit (1 to 5 scale) had greater incidence of metritis, retained placenta, and metabolic disorders (displaced abomasum, milk fever, ketosis) and a longer interval to first breeding than cows that lost $<1$ BCS unit during the transition (Kim and Suh, 2003).

Indicators of NEB are highly correlated with lost milk production, increased disease incidence, and decreased fertility. However, the extent to which NEB is causative for peripartal health problems rather than just a correlated phenomenon must be examined critically. For example, in transition cows, inflammatory responses may decrease DMI, cause alterations in metabolism, and predispose cows to greater NEB or increased disease (Graugnard et al., 2012, 2013). Inducing a degree of calculated NEB in mid-lactation cows similar to what periparturient cows often encounter does not result in marked increases in ketogenesis or other processes associated with peripartal disease (Moyes et al., 2009). Nevertheless, early postpartal increases in serum NEFA and decreases in serum glucose concentrations were negatively associated with pregnancy at first insemination in a timed artificial insemination (TAI) program (Garverick et al., 2013). Although serum concentrations of NEFA and glucose were not different between cows that ovulated or did not ovulate before TAI, the probability of pregnancy decreased with greater serum NEFA and increased with greater serum glucose concentrations at d 3 postpartum (Garverick et al., 2013). In support of these findings, early occurrence of subclinical ketosis is more likely to decrease milk yield and compromise fertility (McArt et al., 2012). McArt et al. (2012) reported that cows with subclinical ketosis detected between 3 and $7 \mathrm{~d}$ after calving were 0.7 times as likely to conceive to first service and 4.5 times more likely to be removed from the herd within the first 30
DIM compared with cows that developed ketosis at 8 d or later.

Cows that successfully adapt to lactation and avoid metabolic or physiological imbalance are able to support both high milk production and successful reproduction while remaining healthy. Decreased fertility in the face of increasing milk production may be attributed to greater severity of postpartal NEB resulting from inadequate transition management or increased rates of disease. Competition for nutrients between the divergent outcomes during early lactation and subsequent pregnancy will delay reproductive function. Because NEB interrupts reproduction in most species, including humans, inappropriate nutritional management may predispose cows to both metabolic disturbances and impaired reproduction. Cows must make "metabolic decisions" about where to direct scarce resources, and in early lactation, nutrients will be directed to milk production rather than to the next pregnancy (Bauman and Currie, 1980).

Different nutritional strategies have been proposed to improve reproduction of the dairy cow with no detrimental effect on lactation performance. Feeding highquality forages, CE diets, and negative DCAD prepartum are some of the most common ways to regulate energy intake in cows (Cardoso et al., 2013; Drackley and Cardoso, 2014; Santos et al., 2019). Reproduction of dairy cattle may benefit by maximizing nutrient intake during the transition period and minimizing the incidence of periparturient problems (Cardoso et al., 2013; Drackley and Cardoso, 2014).

\section{DIETARY CONSIDERATIONS DURING THE TRANSITION PERIOD}

\section{Controlled-Energy Diet}

Controlling energy intake during the dry period to near calculated requirements leads to transition success (Dann et al., 2005, 2006; Janovick et al., 2011; Graugnard et al., 2012, 2013). Benefits of feeding CE diets prepartum to dairy cows have been reported (Dann et al., 2006; Douglas et al., 2006; Janovick and Drackley, 2010; Cardoso et al., 2013). Janovick et al. (2011) suggested that cows fed CE during the dry period had fewer diseases and disorders than cows fed high-energy diets. Also, Beever (2006) stated that farmers have repeatedly observed easier calving and greater DMI around parturition when energy intake is controlled prepartum. Excess energy consumption prepartum also seems to result in a larger decline in DMI prepartum compared with cows having controlled intake prepartum (Janovick et al., 2011). Such steep changes in DMI 
prepartum have been associated with increased deposition of lipid in liver postpartum (Drackley et al., 2005). From a practical standpoint, the CE approach may simplify dry cow management by avoiding social stress due to group changes (Cook and Nordlund, 2009) and allowing a single group feeding instead of the 2-group approach (Dann et al., 2006).

Other research groups (Rukkwamsuk et al., 1998; Holcomb et al., 2001; Holtenius et al., 2003; Vickers et al., 2013) have reached similar conclusions about CE intake during the dry period, although not all studies have shown benefits (Winkelman et al., 2008). Whitaker et al. (1993) reported increased health problems during the transition period or poor reproductive success when cows were fed with low-energy dry cow diets. However, results must be examined carefully to discern whether nutrient intakes were adequate. Even cows fed moderate-energy diets (1.50 to $1.60 \mathrm{Mcal}$ of $\mathrm{NE}_{\mathrm{L}} / \mathrm{kg}$ of $\mathrm{DM}$ ) will consume 40 to $80 \%$ more energy than required during both far-off and close-up periods (Dann et al., 2005, 2006). Cows in these studies were all less than 3.5 BCS (1 to 5 scale) at dry-off and were individually fed a TMR based on corn silage, alfalfa silage, and alfalfa hay with some concentrate supplementation. Data indicate that allowing cows to over-consume energy may predispose them to health problems during the transition period if they face stressors or challenges that limit DMI (Cardoso et al., 2013). There are advantages of having a 2-stage dietary strategy (i.e., far-off and close-up) in comparison to a 1-stage dietary strategy throughout the entire dry period (Contreras et al., 2004; Richards, 2011). Contreras et al. (2004) concluded that a 2-stage dietary strategy was preferred, and BCS at dry off should be considered when determining grouping and nutritional strategies for dry cows. Thinner (BCS $\leq 3.0$ ) cows at dry off fed a close-up diet for $21 \mathrm{~d}$ produced the most milk and fatter (BCS $\geq 3.25$ ) cows fed the same strategy produced the least amount of milk. Applicable field decisions extracted from the aforementioned studies (and others) should be evaluated carefully because, in practical scenarios, cows may have higher BCS and BCS variation.

Prolonged over-consumption of energy during the dry period can decrease postcalving DMI. Over-consuming energy results in negative responses of metabolic indicators, such as higher NEFA and BHB in blood and more triacylglycerol in the liver after calving (Janovick et al., 2011). Alterations in cellular and gene-level responses in liver (Loor et al., 2006) and adipose tissue (Ji et al., 2012) potentially explain many of the changes at the cow level. Over-consumption of energy during the close-up period increases the enzymatic "machinery" in adipose tissue for triacylglycerol mobilization after calving, with transcriptional changes leading to decreased lipogenesis (fat synthesis), increased lipolysis (fat utilization), and decreased ability of insulin to inhibit lipolysis (Ji et al., 2012). Controlling energy intake during the dry period also improved neutrophil function postpartum (Graugnard et al., 2012) and may lead to better immune function.

Allowing dry cows to consume more energy than required, even if cows do not become noticeably overconditioned, results in responses that would be typical of obese cows. Because energy that cows consume in excess of their requirements must either be dissipated as heat or stored as fat, we postulated that this excess is accumulated preferentially in internal adipose tissue depots in some cows. Moderate over-consumption of energy by nonlactating cows for $57 \mathrm{~d}$ led to greater deposition of fat in abdominal adipose tissues (omental, mesenteric, and perirenal) than in cows fed a high-bulk diet to control energy intake to near requirements (Drackley et al., 2014). Serum NEFA and signaling molecules released by visceral adipose tissues travel directly to the liver, which may cause fatty liver, subclinical ketosis, and secondary problems with liver function.

Nutritionally balanced diets must be fed and the TMR must be physically processed appropriately so that cows do not sort the bulkier ingredients. Feeding bulky forage separately from a partial TMR, or improper forage processing (i.e., nonhomogeneous chop length of the forage) will lead to variable intake among cows, with some consuming too much energy and some too little (DeVries et al., 2005). Underfeeding relative to requirements, where nutrient balance also is likely limiting, leads to increased incidence of retained placenta and metritis (Mulligan et al., 2006). Merely adding straw to a diet is not the key principle; rather, the diet must be formulated to limit energy intake (approximately 1.4 Mcal of $\mathrm{NE}_{\mathrm{L}} / \mathrm{kg}$ of $\mathrm{DM}$, to limit intake to about 15 to $16 \mathrm{Mcal} / \mathrm{d}$ for typical Holstein cows), and at the same time meet the requirements for protein, minerals, and vitamins.

Less is known about diet formulation for the immediate postpartum period to optimize transition success and subsequent reproduction. Proper dietary formulation during the dry period or close-up period will maintain or enable rumen adaptation to higher grain diets after calving. Failure to do so may compromise early lactation productivity. For example, Silva-delRio et al. (2010) attempted to duplicate the dietary strategy of Dann et al. (2006) by feeding either a lowenergy far-off diet for 5 wk followed by a higher-energy diet for the last $3 \mathrm{wk}$ before parturition, or by feeding the higher-energy diet for the entire 8-wk dry period. Authors reported that cows fed the higher-energy diet for only 3 wk before parturition produced less milk than cows fed the diet for 8 wk (43.8 vs. $48.5 \mathrm{~kg} / \mathrm{d}$ ). 
However, the far-off dry period diet contained $55.1 \%$ alfalfa silage and $38.5 \%$ wheat straw but no corn silage. In comparison, the higher-energy dry period diet and the early lactation diet both contained $35 \%$ corn silage. Ruminal adaptation likely was insufficient for cows fed the higher energy diet for only 3 wk. Mann et al. (2015) reported no difference in milk yield when cows were fed controlled, medium, or high-energy diets prepartum.

Recently, researchers have reported that Holstein cows consuming a prepartum diet $(29 \%$ wheat straw on a DM basis; $13.2 \% \mathrm{CP}, 1.5$ Mcal of $\mathrm{NE}_{\mathrm{L}} / \mathrm{kg}$ ) with wheat straw chopped shorter (short straw chopped) had greater TMR DMI $(15.6 \mathrm{~kg} / \mathrm{d} ; \mathrm{SE}=0.16)$ in the dry period than cows consuming wheat straw chopped longer (long straw chopped; $15.0 \mathrm{~kg} / \mathrm{d} ; \mathrm{SE}=0.16$ ) (Havekes et al., 2019). Wheat straw was chopped using a bale processor using a $2.54-\mathrm{cm}$ screen for the short straw chopped and a 10.16-cm screen for the long straw chopped (Havekes et al., 2019). Additionally, cows consuming the longer chopped wheat straw had higher blood BHB in the wk 3 postcalving than cows consuming the shorter chopped wheat straw $(1.3 \pm 0.11$ vs. 0.8 $\pm 0.10 \mathrm{mmol} / \mathrm{L}$; respectively) (Havekes et al., 2019). It is still to be determined if particle size and sorting is even more relevant in moderate- to high-energy diets (1.5 Mcal of $\mathrm{NE}_{\mathrm{L}} / \mathrm{kg}$ ) when compared with $\mathrm{CE}$ diets (1.3 Mcal of $\mathrm{NE}_{\mathrm{L}} / \mathrm{kg}$ ) prepartum.

A major area of concern in the fresh cow period is the sudden increase in dietary energy density leading to SARA, which can decrease DMI and digestibility of nutrients. Adequate physical form of the diet, derived either from ingredients or mixing strategy, is needed to stimulate ruminal activity and chewing behavior. Dietary starch content and fermentability likely interact with forage characteristics and ration physical form. Dann and Nelson (2011) compared 3 dietary starch contents (primarily from corn starch) in the fresh cow period for cows fed a CE-type ration in the dry period. Milk production was greatest when starch content was moderate $(23.2 \%$ of $\mathrm{DM})$ or low $(21.0 \%$ of $\mathrm{DM})$ in the fresh cow diet compared with high $(25.5 \%$ of DM). If SARA decreases DMI and nutrient availability to the cow, serum NEFA from adipose tissue mobilization and increased ketogenesis may follow.

In addition, rapid starch fermentation in the presence of serum NEFA leads to bursts of propionate reaching the liver, which may decrease feeding activity and DMI according the hepatic oxidation theory (Allen et al., 2009). A moderate starch content (23 to $25 \%$ of DM) with a rate of moderate starch fermentation rate (e.g., ground dry corn rather than high-moisture corn or ground barley) along with adequate effective forage fiber may be the best strategy for fresh cows (Allen et al., 2009). Research also has demonstrated that high-grain diets may lead to greater numbers of gramnegative bacteria such as Escherichia coli resulting in increases of endotoxin present in the rumen. This may decrease barrier function and inflammatory responses in the cow (Zebeli and Metzler-Zebeli, 2012). Interestingly enough, the authors reported no statistical difference for DMI and milk yield from cows that were least, intermediate, or most acidotic.

\section{Prepartum Negative DCAD Diets}

Treatments to lessen the effects of $\mathrm{HC}$ and $\mathrm{SCH}$ have been in use for decades; however, feeding management as a prevention of $\mathrm{Ca}$ imbalance at parturition has become more commonly used in recent years (Horst et al., 1997; Goff, 2008; Reinhardt et al., 2011). Overfeeding $\mathrm{Ca}$ in the last 4 wk before parturition has been associated with high incidences of SCH and HC (Horst, 1986; Overton and Waldron, 2004) resulting in the development of new dietary strategies.

Others have established that feeding acidogenic salts or products to prepartum negative DCAD diets improved concentrations of $\mathrm{Ca}$ in blood at calving, reduced the risk of $\mathrm{HC}$ and uterine diseases, and improved lactation performance (Oetzel et al., 1991; Santos et al., 2019; Ryan et al., 2020). Goff and Koszewski (2018) reported that $0.46 \% \mathrm{Ca}$ diets prepartum were not low enough in Ca to stimulate parathyroid hormone secretion and place the cow in negative Ca balance before calving. Adding anions to a diet can benefit periparturient cow plasma Ca concentration, but only if it alters acid-base status enough to reduce urine $\mathrm{pH}$ below 7.5 (Goff and Koszewski, 2018).

Santos et al. (2019) concluded that, in nulliparous cows, reduction in dietary DCAD prepartum either depressed or did not affect their performance. The limited number of experiments with nulliparous cows did not provide sufficient evidence for a recommended DCAD for this group (Santos et al., 2019). Authors' criteria for inclusion and exclusion of experiments in the meta-analysis did not include urine $\mathrm{pH}$ but only manipulation of the DCAD of prepartum diets or that prepartum cows had been fed acidogenic diets and that the concentrations of $\mathrm{Ca}, \mathrm{P}$, or $\mathrm{Mg}$ were manipulated (Santos et al., 2019). Therefore, information regarding dietary $\mathrm{Ca}$ concentrations and degree of acidification (fully acidified diets; urine $\mathrm{pH}$ between 5.5 and 6 ; and partially acidified diets, urine $\mathrm{pH}$ between 6 and 7.5) at similar negative DCAD in prepartum diets still deserves attention.

In a recent study performed at the University of Illinois, multiparous Holstein cows were enrolled to evaluate the effects of feeding a negative DCAD, fully acidified diet prepartum at 2 different concentrations 
of dietary $\mathrm{Ca}$ on their subsequent reproductive performance. Treatments began at $28 \mathrm{~d}$ before expected calving and were a positive DCAD diet $(\mathbf{C O N} ;+6$ $\mathrm{mEq} / 100 \mathrm{~g}$ of $\mathrm{DM})$ with low dietary $\mathrm{Ca}(0.4 \% \mathrm{DM}$; urine $\mathrm{pH}=8.12$ ); a fully acidified, negative DCAD diet $(\mathrm{ND} ;-24 \mathrm{mEq} / 100 \mathrm{~g}$ of $\mathrm{DM}$; urine $\mathrm{pH}=5.76)$ with low dietary $\mathrm{Ca}(0.4 \% \mathrm{DM})$; and a fully acidified, negative DCAD diet (NDCA; $-24 \mathrm{mEq} / 100 \mathrm{~g}$ of DM; urine $\mathrm{pH}=5.67)$ with high dietary $\mathrm{Ca}(2.0 \% \mathrm{DM}$; Glosson, 2018; Ryan et al., 2020).

The average days to first ovulation postpartum of cows fed NDCA $(16.3 \pm 0.4 \mathrm{~d})$ and cows fed ND $(17.93 \pm 0.6$ d) was lower than cows fed CON $18.93 \pm 0.9 \mathrm{~d}$; Ryan et al., 2020). Development of the DF of the first follicular wave postpartum is highly correlated with conception rates (Butler, 2003). Butler (2003) described a positive association between early commencement of the ovulatory cycle (i.e., days to first ovulation) and increased conception rates at first TAI. The Ca balance seems to be associated with reproductive success in dairy cows. Ryan et al. (2020) reported that cows fed CON [4/19 pregnancy per artificial insemination $(\mathbf{P} / \mathbf{A I})]$ tended to have lower P/AI than cows fed NDCA (11/21 P/AI) but not ND (8/20 P/AI). Additionally, cows fed NDCA tended to have greater intensity of the uterine protein occludin (e.g., Ca dependent tight-junction protein) expression than cows fed ND along with cows fed ND having higher plasma haptoglobin concentrations than cows fed NDCA in the prepartum and postpartum periods (Ryan et al., 2020). Caixeta et al. (2017) reported that cows with abnormal Ca concentrations $(<8.6 \mathrm{mg} /$ $\mathrm{dL}$ ) at the first $3 \mathrm{~d}$ after calving tended to take longer before returning to normal cyclicity.

\section{Importance of $A A$}

Some AA are limiting for optimal milk production as evidenced by an increase in milk yield, milk protein yield, and protein percentage after supplementation with specific, rumen-protected AA. The first 2 limiting AA for milk production are considered to be Met and Lys (NRC, 2001). In addition, many AA can have positive effects on physiological processes that are independent of their effects on synthesis of proteins (Wu et al., 2013). Fertilization and the first few days of embryo development occur in the oviduct. Around $5 \mathrm{~d}$ after fertilization the embryo arrives in the uterine horn. During the time before embryo attachment, the embryo is free-floating and is dependent upon uterine secretions for energy and the building blocks for development, including AA; thus, it is critical to understand the changes in AA concentrations in the uterus that accompany these different stages of embryo development (Forde et al., 2014).
The lipid profile of oocytes and the early embryo can be influenced by the environment of the cow. Acosta et al. (2016) used lactating Holsteins entering their second or greater lactation assigned to 2 treatments from $30 \pm$ 2 DIM to $72 \pm 2$ DIM: control (CON; fed a basal diet with a 3.4:1 Lys:Met) and Met (MET; fed the basal diet plus RPM to a 2.9:1 Lys:Met). Cows were superovulated (FSH) and embryos were flushed $6.5 \mathrm{~d}$ after AI. Thirty-seven embryos were harvested from cows $(\mathrm{MET}=16 ; \mathrm{CON}=21)$. Cows receiving MET had greater lipid accumulation (7.3 arbitrary units) compared with cows receiving CON (3.7 arbitrary units; Acosta et al., 2016). The extra lipid could potentially serve as an important source of energy for the early developing embryo.

The nutrient requirements for complete development of bovine embryos have not yet been determined. Current culture conditions allow development of bovine embryos to the blastocyst stage (d 7 to 8 ) and even allow hatching of a percentage of embryos (d 9); however, conditions have not been developed in vitro that allow elongation of embryos. The Met requirement for cultured preimplantation bovine embryos (d 7 to 8 ) have been determined (Bonilla et al., 2010). The Met requirement was surprisingly low $(7 \mu M$ for development of embryos to the blastocyst stage by d 7); however, development to the advanced blastocyst stage by $\mathrm{d} 7$ appeared to be optimized at around $21 \mu M$ (Bonilla et al., 2010).

Forde et al. (2014) evaluated the AA content of uterine luminal fluid and expression of AA transporters in the endometrium during the estrous cycle and peri-implantation period of early pregnancy in crossbred beef heifers. The concentration of detectable AA in uterine luminal fluid increased as development of the blastocyst progressed to an elongated filamentous conceptus. Authors proposed that the transport of AA into the uterine lumen contributes to the capacity of the uterus to stimulate elongation of the conceptus during the peri-implantation period of pregnancy in cattle. Unfortunately, authors do not report plasma amino acid concentration. Stella et al. (2018) reported that the plasma concentrations of cows fed RPM or not (CON) at breeding (73 DIM) were approximately 27 and $15 \mu M$, respectively. Therefore, based on the aforementioned studies, one could hypothesize that an optimal plasma Met concentrations should be achieved for improved reproductive performance; however, that is still to be determined.

Toledo et al. (2017) reported on 309 cows (138 primiparous and 171 multiparous) randomly assigned to 2 treatments from 28 to 128 DIM: (1) CON: cows fed a ration formulated to deliver 2,500 $\mathrm{g}$ of MP with $6.9 \%$ Lys and 1.9\% Met (as a \% of MP) and (2) RPM: cows 
fed a ration formulated to deliver 2,500 $\mathrm{g}$ of MP with $6.9 \%$ Lys and $2.3 \%$ Met (as a \% of MP). Cows were inseminated and pregnancy checked at $28 \mathrm{~d}$ (plasma pregnancy specific protein-B concentration), and at 32 , 47 , and $61 \mathrm{~d}$ (ultrasound). No statistical differences were observed in milk production, but milk from cows in RPM had a higher protein concentration. Additionally, multiparous cows in RPM tended to have a lower pregnancy loss from 28 to $61 \mathrm{~d}$ after AI than multiparous cows in CON (6.1 and 19.6\%, respectively). Pregnancy losses during d 28 and 61 were not different in primiparous cows fed RPM or CON (14.6 and 12.8\%, respectively; Toledo et al., 2017). Recently, the relationship between RPM supplementation to dairy cows and the uterine environment have been established (Skenandore et al., 2017; Stella et al., 2018). Higher proportions of PMN from endometrial cytology of dairy cows receiving RPM at 15 DIM but lower PMN at 72 DIM than cows not receiving RPM is an indication of improved uterine environment (Stella et al., 2018). Results from Stella et al. (2018) agree with LeBlanc (2014), who proposed that healthy cows (i.e., without endometritis) can build an immunological response early in lactation.

Perhaps the most detrimental effect of NEB on reproductive performance is delayed return to cyclicity. Dominant follicle growth and estradiol production are key factors for a successful conception, and their impairment can be attributed to reduced LH pulses and decreased circulating insulin and IGF-I concentrations (Komaragiri and Erdman, 1997). Furthermore, immune function is also suppressed during the periparturient period. Negative energy balance and fatty liver syndrome have been shown to impair peripheral blood neutrophil function (Hammon et al., 2006). Acosta et al. (2017) reported that Met and choline supplementation induced a downregulation of pro-inflammatory genes, possibly indicating lower inflammatory processes in follicular cells of the first DF postpartum.

It has been proposed that mRNA expression of the LH receptor (LHCGR; Bao et al., 1997a) and 3 - $\beta$-hydroxysteroid dehydrogenase in granulosa cells can play a role in the establishment of follicular selection (Bao et al., 1997b). Supplementing Met during the transition period increased 3 - $\beta$-hydroxysteroid dehydrogenase expression in the follicular cells of the first DF postpartum (Acosta et al., 2017). Higher Met concentrations in the follicular fluid of supplemented cows can potentially affect oocyte quality (Acosta et al., 2017). Understanding how this may affect reproductive performance in commercial farms needs to be further investigated. Batistel et al. (2017) reported that studies with nonruminant species argue for the potential relevance of the maternal Met supply during late gestation may enhance utero-placental uptake and transport of nutrients. The authors hypothesized that the greater newborn BW of calves from cows fed RPM compared with CON (42 vs. $44 \mathrm{~kg}$ ) may be a direct response to greater nutrient supply from the feed intake response induced by Met. The fact that certain AA and glucose induce motor signaling to different degrees is highly suggestive of nutrient-specific mechanistic responses.

\section{CONCLUSIONS}

Formulation and delivery of appropriate diets that limit total energy intake to requirements but also provide proper amounts of all other nutrients before calving can help lessen the extent of NEB after calving. Effects of such diets on indicators of metabolic health are generally positive, suggesting the potential to lessen effects of periparturient disease on fertility. Providing a fully acidified negative DCAD diet prepartum, with appropriate dietary Ca concentrations $(2.0 \%$ of $\mathrm{DM})$, improved reproductive performance of dairy cows. Dietary supplementation of cows with RPM and rumenprotected Lys improved health and reproductive performance of dairy cows. Methionine supplementation seems to affect the preimplantation embryo in a way that enhances its capacity for survival. Dairy farmers, veterinarians, and nutritionists should consider a combination of well-established strategies for improved cow performance, since applicable field decisions depend on practical scenarios.

\section{ACKNOWLEDGMENTS}

This project was partially supported by the USDA National Institute of Food and Agriculture (Washington, DC; NC-2042). Sincere appreciation is expressed to all the members of the NC-2042 group, along with colleagues at the University of Illinois and US Dairy Forage Research Center. The authors have not stated any conflicts of interest.

\section{REFERENCES}

Acosta, D. A. V., A. C. Denicol, P. Tribulo, M. I. Rivelli, C. Skenandore, Z. Zhou, D. Luchini, M. N. Corrêa, P. J. Hansen, and F. C. Cardoso. 2016. Effects of rumen-protected methionine and choline supplementation on the preimplantation embryo in Holstein cows. Theriogenology 85:1669-1679. https://doi.org/10.1016/j .theriogenology.2016.01.024.

Acosta, D. A. V., M. I. Rivelli, C. Skenandore, Z. Zhou, D. H. Keisler, D. Luchini, M. N. Corrêa, and F. C. Cardoso. 2017. Effects of rumen-protected methionine and choline supplementation on steroidogenic potential of the first postpartum dominant follicle and expression of immune mediators in Holstein cows. Theriogenology 96:1-9. https://doi.org/10.1016/j.theriogenology.2017.03.022.

Allen, M. S., B. J. Bradford, and M. Oba. 2009. Board Invited Review: The hepatic oxidation theory of the control of feed intake and its application to ruminants. J. Anim. Sci. 87:3317-3334. https://doi .org/10.2527/jas.2009-1779. 
Bach, A., N. Valls, A. Solans, and T. Torrent. 2008. Association between nondietary factors and dairy herd performance. J. Dairy Sci. 91:3259-3267. https://doi.org/10.3168/jds.2008-1030.

Bao, B., H. A. Garverick, G. W. Smith, M. F. Smith, B. E. Salfen, and R. S. Youngquist. 1997a. Changes in messenger ribonucleic acid encoding luteinizing hormone receptor, cytochrome P450-side chain cleavage, and aromatase are associated with recruitment and selection of bovine ovarian follicles. Biol. Reprod. 56:1158e68.

Bao, B., H. A. Garverick, G. W. Smith, M. F. Smith, B. E. Salfen, and R. S. Youngquist. 1997b. Expression of messenger ribonucleic acid (mRNA) encoding 3beta-hydroxysteroid dehydrogenase delta4, delta5 isomerase (3beta-HSD) during recruitment and selection of bovine ovarian follicles: Identification of dominant follicles by expression of 3beta-HSD mRNA within the granulosa cell layer. Biol. Reprod. 56:1466e73.

Batistel, F., A. S. M. Alharthi, L. Wang, C. Parys, Y. Pan, F. C. Cardoso, and J. J. Loor. 2017. Placentome nutrient transporters and motor signaling proteins are altered by methionine supply during late-gestation in dairy cows and are associated with newborn birth weight. J. Nutr. 147:1640-1647.

Bauman, D. E., and W. B. Currie. 1980. Partitioning of nutrients during pregnancy and lactation: A review of mechanisms involving homeostasis and homeorhesis. J. Dairy Sci. 63:1514-1529. https:// doi.org/10.3168/jds.S0022-0302(80)83111-0.

Beever, D. E. 2006. The impact of controlled nutrition during the dry period on dairy cow health, fertility and performance. Anim. Reprod. Sci. 96:212-226. https://doi.org/10.1016/j.anireprosci.2006 .08 .002 .

Bell, A. W. 1995. Regulation of organic nutrient metabolism during transition from late pregnancy to early lactation. J. Anim. Sci. 73:2804-2819. https://doi.org/10.2527/1995.7392804x.

Bonilla, L., D. Luchini, E. Devillard, and P. J. Hansen. 2010. Methionine requirements for the preimplantation bovine embryo. J. Reprod. Dev. 56:527-532. https://doi.org/10.1262/jrd.10-037H.

Butler, W. R. 2003. Energy balance relationships with follicular development, ovulation and fertility in postpartum dairy cows. Livest. Prod. Sci. 83:211-218. https://doi.org/10.1016/S0301 $-6226(03) 00112-\mathrm{X}$

Caixeta, L. S., P. A. Ospina, M. B. Capel, and D. V. Nydam. 2017. Association between subclinical hypocalcemia in the first 3 days of lactation and reproductive performance of dairy cows. Theriogenology 94:1-7. https://doi.org/10.1016/j.theriogenology.2017.01 .039 .

Cardoso, F. C., S. J. Leblanc, M. R. Murphy, and J. K. Drackley. 2013. Prepartum nutritional strategy affects reproductive performance in dairy cows. J. Dairy Sci. 96:5859-5871. https://doi.org/ 10.3168/jds.2013-6759.

Chapinal, N., S. J. LeBlanc, M. E. Carson, K. E. Leslie, S. Godden, M. Capel, J. E. P. Santos, M. W. Overton, and T. F. Duffield. 2012. Herd-level association of serum metabolites in the transition period with disease, milk production, and early lactation reproductive performance. J. Dairy Sci. 95:5676-5682. https://doi.org/10 $.3168 /$ jds.2011-5132.

Charbonneau, E., D. Pellerin, and G. R. Oetzel. 2006. Impact of lowering dietary cation-anion difference in nonlactating dairy cows: A meta-analysis. J. Dairy Sci. 89:537-548. https://doi.org/10.3168/ jds.S0022-0302(06)72116-6.

Contreras, L. L., C. M. Ryan, and T. R. Overton. 2004. Effects of dry cow grouping strategy and prepartum body condition score on performance and health of transition dairy cows. J. Dairy Sci. 87:517-523. https://doi.org/10.3168/jds.S0022-0302(04)73191-4.

Cook, N. B., and K. V. Nordlund. 2009. The influence of the environment on dairy cow behavior, claw health and herd lameness dynamics. Vet. J. 179:360-369. https://doi.org/10.1016/j.tvjl.2007 .09 .016

Crowe, M. A., M. Hostens, and G. Opsomer. 2018. Reproductive management in dairy cows - The future. Ir. Vet. J. 71:1-13. https://doi .org/10.1186/s13620-017-0112-y.

Dann, H. M., N. B. Litherland, J. P. Underwood, M. Bionaz, A. D'Angelo, J. W. McFadden, and J. K. Drackley. 2006. Diets during far-off and close-up dry periods affect periparturient metabolism and lactation in multiparous cows. J. Dairy Sci. 89:3563-3577. https://doi.org/10.3168/jds.S0022-0302(06)72396-7.

Dann, H. M., D. E. Morin, G. A. Bollero, M. R. Murphy, and J. K. Drackley. 2005. Prepartum intake, postpartum induction of ketosis, and periparturient disorders affect the metabolic status of dairy cows. J. Dairy Sci. 88:3249-3264. https://doi.org/10.3168/ jds.S0022-0302(05)73008-3.

Dann, H. M., and B. H. Nelson. 2011. Early lactation diets for dairy cattle-Focus on starch. Pages 46-56 in Proceedings of the 2011 Cornell Nutrition Conference for Feed Manufacturers, Syracuse, NY. Department of Animal Science, Cornell University, Ithaca, NY.

DeGaris, P. J., and I. J. Lean. 2008. Milk fever in dairy cows: A review of pathophysiology and control principles. Vet. J. 176:58-69. https: //doi.org/10.1016/j.tvjl.2007.12.029.

DeVries, T. J., M. A. G. von Keyserlingk, and K. A. Beauchemin. 2005. Frequency of feed delivery affects the behavior of lactating dairy cows. J. Dairy Sci. 88:3553-3562. https://doi.org/10.3168/ jds.S0022-0302(05)73040-X.

Douglas, G. N., T. R. Overton, H. G. Bateman II, H. M. Dann, and J. K. Drackley. 2006. Prepartal plane of nutrition, regardless of dietary energy source, affects periparturient metabolism and dry matter intake in Holstein cows. J. Dairy Sci. 89:2141-2157. https: //doi.org/10.3168/jds.S0022-0302(06)72285-8.

Drackley, J. K. 1999. Biology of dairy cows during the transition period: The final frontier? J. Dairy Sci. 82:2259-2273. https://doi .org/10.3168/jds.S0022-0302(99)75474-3.

Drackley, J. K., and F. C. Cardoso. 2014. Prepartum and postpartum nutritional management to optimize fertility in high-yielding dairy cows in confined TMR systems. Animal 8(s1):5-14. https://doi .org/10.1017/S1751731114000731.

Drackley, J. K., H. M. Dann, N. Douglas, N. A. J. Guretzky, N. B. Litherland, J. P. Underwood, and J. J. Loor. 2005. Physiological and pathological adaptations in dairy cows that may increase susceptibility to periparturient diseases and disorders. Ital. J. Anim. Sci. 4:323-344. https://doi.org/10.4081/ijas.2005.323.

Drackley, J. K., R. L. Wallace, D. Graugnard, J. Vasquez, B. F. Richards, and J. J. Loor. 2014. Visceral adipose tissue mass in nonlactating dairy cows fed diets differing in energy density. J. Dairy Sci. 97:3420-3430. https://doi.org/10.3168/jds.2014-8014.

Forde, N., C. A. Simintiras, R. Sturmey, S. Mamo, A. K. Kelly, T. E. Spencer, F. W. Bazer, and P. Lonergan. 2014. Amino acids in the uterine luminal fluid reflects the temporal changes in transporter expression in the endometrium and conceptus during early pregnancy in cattle. PLoS One 9:e100010. https://doi.org/10.1371/ journal.pone.0100010.

Garverick, H. A., M. N. Harris, R. Vogel-Bluel, J. D. Sampson, J. Bader, W. R. Lamberson, J. N. Spain, M. C. Lucy, and R. S. Youngquist. 2013. Concentrations of nonesterified fatty acids and glucose in blood of periparturient dairy cows are indicative of pregnancy success at first insemination. J. Dairy Sci. 96:181-188. https://doi.org/10.3168/jds.2012-5619.

Glosson, K. 2018. Investigating the effect of yeast and mineral dietary supplements during the periparturient period on the production, physical health, and innate immune system of dairy cows. PhD Thesis, Department of Animal Sciences, University of Illinois, Urbana.

Goff, J. P. 2008. The monitoring, prevention, and treatment of milk fever and subclinical hypocalcemia in dairy cows. Vet. J. 176:50-57. https://doi.org/10.1016/j.tvjl.2007.12.020.

Goff, J. P., and N. J. Koszewski. 2018. Comparison of $0.46 \%$ calcium diets with and without added anions with a $0.7 \%$ calcium anionic diet as a means to reduce periparturient hypocalcemia. J. Dairy Sci. 101:5033-5045. https://doi.org/10.3168/jds.2017-13832.

Graugnard, D. E., M. Bionaz, E. Trevisi, K. M. Moyes, J. L. SalakJohnson, R. L. Wallace, J. K. Drackley, G. Bertoni, and J. J. Loor. 2012. Blood immunometabolic indices and polymorphonuclear neutrophil function in peripartum dairy cows are altered by level of dietary energy prepartum. J. Dairy Sci. 95:1749-1758. https:// doi.org/10.3168/jds.2011-4579. 
Graugnard, D. E., K. M. Moyes, E. Trevisi, M. J. Khan, D. Keisler, J. K. Drackley, G. Bertoni, and J. J. Loor. 2013. Liver lipid content and inflammometabolic indices in peripartal dairy cows are altered in response to prepartal energy intake and postpartal intramammary inflammatory challenge. J. Dairy Sci. 96:918-935. https:// doi.org/10.3168/jds.2012-5676.

Griffin, J. F. T., P. J. Hartigan, and W. R. Nunn. 1974. Non-specific uterine infection and bovine fertility: I. Infection patterns and endometritis during the first seven weeks post-partum. Theriogenology 1:91-106. https://doi.org/10.1016/0093-691X(74)90052-1.

Hammon, D. S., I. M. Evjen, T. R. Dhiman, J. P. Goff, and J. L. Walters. 2006. Neutrophil function and energy status in Holstein cows with uterine health disorders. Vet. Immunol. Immunopathol. 113:21-29. https://doi.org/10.1016/j.vetimm.2006.03.022.

Havekes, C. D., T. F. Duffield, A. J. Carpenter, and T. J. DeVries. 2019. Effect of wheat straw chop length in high-straw dry cow diets on intake, health, and performance of dairy cows across the transition period. J. Dairy Sci. 103:254-271. https://doi.org/10 .3168/jds.2019-17033.

Holcomb, C. S., H. H. Van Horn, H. H. Head, M. B. Hall, and C. J. Wilcox. 2001. Effects of prepartum dry matter intake and forage percentage on postpartum performance of lactating dairy cows. J. Dairy Sci. 84:2051-2058. https://doi.org/10.3168/jds.S0022 -0302(01)74649-8.

Holtenius, K., S. Agenäs, C. Delavaud, and Y. Chilliard. 2003. Effects of feeding intensity during the dry period. 2. Metabolic and hormonal responses. J. Dairy Sci. 86:883-891. https://doi.org/10 .3168/jds.S0022-0302(03)73671-6.

Horst, R. L. 1986. Regulation of calcium and phosphorus homeostasis in the dairy cow. J. Dairy Sci. 69:604-616. https://doi.org/10 .3168/jds.S0022-0302(86)80445-3.

Horst, R. L., J. P. Goff, T. A. Reinhardt, and D. R. Buxton. 1997. Strategies for preventing milk fever in dairy cattle. J. Dairy Sci. 80:1269-1280. https://doi.org/10.3168/jds.S0022-0302(97)76056 -9 .

Janovick, N. A., Y. R. Boisclair, and J. K. Drackley. 2011. Prepartum dietary energy intake affects metabolism and health during the periparturient period in primiparous and multiparous Holstein cows. J. Dairy Sci. 94:1385-1400. https://doi.org/10.3168/jds.2010 -3303 .

Janovick, N. A., and J. K. Drackley. 2010. Prepartum dietary management of energy intake affects postpartum intake and lactation performance by primiparous and multiparous Holstein cows. J. Dairy Sci. 93:3086-3102. https://doi.org/10.3168/jds.2009-2656.

Ji, P., J. Osorio, J. K. Drackley, and J. J. Loor. 2012. Overfeeding a moderate energy diet prepartum does not impair bovine subcutaneous adipose tissue insulin signal transduction and induces marked changes in peripartal gene network expression. J. Dairy Sci. 95:4333-4351. https://doi.org/10.3168/jds.2011-5079.

Kim, I. H., and G. H. Suh. 2003. Effect of the amount of body condition loss from the dry to near calving periods on the subsequent body condition change, occurrence of postpartum diseases, metabolic parameters and reproductive performance in Holstein dairy cows. Theriogenology 60:1445-1456. https://doi.org/10.1016/ S0093-691X(03)00135-3.

Kimura, K., T. A. Reinhardt, and J. P. Goff. 2006. Parturition and hypocalcemia blunts calcium signals in immune cells of dairy cattle. J. Dairy Sci. 89:2588-2595. https://doi.org/10.3168/jds.S0022 -0302(06)72335-9.

Komaragiri, M. V., and R. A. Erdman. 1997. Factors affecting body tissue mobilization in early lactation dairy cows. 1. Effect of dietary protein on mobilization of body fat and protein. J. Dairy Sci. 80:929-937. https://doi.org/10.3168/jds.S0022-0302(97)76016-8.

LeBlanc, S. J. 2010. Assessing the association of the level of milk production with reproductive performance in dairy cattle. J. Reprod. Dev. 56(Suppl.):S1-S7. https://doi.org/10.1262/jrd.1056S01.

LeBlanc, S. J. 2014. Reproductive tract inflammatory disease in postpartum dairy cows. Animal 8(s1):54-63. https://doi.org/10.1017/ S1751731114000524.

Liang, D., L. M. Arnold, C. J. Stowe, R. J. Harmon, and J. M. Bewley. 2017. Estimating US dairy clinical disease costs with a stochastic simulation model. J. Dairy Sci. 100:1472-1486. https://doi.org/10 .3168/jds.2016-11565.

Loor, J. J., H. M. Dann, N. A. Janovick-Guretzky, R. E. Everts, R. Oliveira, C. A. Green, N. B. Litherland, S. L. Rodriguez-Zas, H. A. Lewin, and J. K. Drackley. 2006. Plane of nutrition prepartum alters hepatic gene expression and function in dairy cows as assessed by longitudinal transcript and metabolic profiling. Physiol. Genomics 27:29-41. https://doi.org/10.1152/physiolgenomics .00036 .2006 .

Mann, S., F. A. Leal Yepes, T. R. Overton, J. J. Wakshlag, A. L. Lock, C. M. Ryan, and D. V. Nydam. 2015. Dry period plane of energy: Effects on feed intake, energy balance, milk production, and composition in transition dairy cows. J. Dairy Sci. 98:3366-3382. https://doi.org/10.3168/jds.2014-9024.

Martinez, N., R. M. Rodney, E. Block, L. L. Hernandez, C. D. Nelson, I. J. Lean, and J. E. P. Santos. 2018. Effects of prepartum dietary cation-anion difference and source of vitamin $\mathrm{D}$ in dairy cows: Health and reproductive responses. J. Dairy Sci. 101:2563-2578. https://doi.org/10.3168/jds.2017-13740.

McArt, J. A., D. V. Nydam, and G. R. Oetzel. 2012. Epidemiology of subclinical ketosis in early lactation dairy cattle. J. Dairy Sci. 95:5056-5066. https://doi.org/10.3168/jds.2012-5443.

Moyes, K. M., J. K. Drackley, J. L. Salak-Johnson, D. E. Morin, J. C. Hope, and J. J. Loor. 2009. Dietary-induced negative energy balance has minimal effects on innate immunity during a Streptococcus uberis mastitis challenge in dairy cows during mid-lactation. J. Dairy Sci. 92:4301-4316. https://doi.org/10.3168/jds.2009-2170.

Mulligan, F. J., L. O'Grady, D. A. Rice, and M. L. Doherty. 2006. A herd health approach to dairy cow nutrition and production diseases of the transition cow. Anim. Reprod. Sci. 96:331-353. https: //doi.org/10.1016/j.anireprosci.2006.08.011.

NRC. 2001. Nutrient Requirements of Dairy Cattle. 7th rev. ed. Natl. Acad. Press, Washington, DC.

Oetzel, G. R. 2011. Non-infectious diseases: Milk fever. Pages 239-245 in Encyclopedia of Dairy Sciences. Vol. 2. J. W. Fuquay, P. F. Fox, and P. L. H. McSweeney, ed. Academic Press, San Diego, CA.

Oetzel, G. R., M. J. Fettman, D. W. Hamar, and J. D. Olson. 1991. Screening of anionic salts for palatability, effects on acid-base status, and urinary calcium excretion in dairy cows. J. Dairy Sci. 74:965-971. https://doi.org/10.3168/jds.S0022-0302(91)78245-3.

Ordway, R. S., S. E. Boucher, N. L. Whitehouse, C. G. Schwab, and B. K. Sloan. 2009. Effects of providing two forms of supplemental methionine to periparturient Holstein dairy cows on feed intake and lactational performance. J. Dairy Sci. 92:5154-5166. https:// doi.org/10.3168/jds.2009-2259.

Osorio, J. S., P. Ji, J. K. Drackley, D. Luchini, and J. J. Loor. 2013. Supplemental Smartamine M or metasmart during the transition period benefits postpartal cow performance and blood neutrophil function. J. Dairy Sci. 96:6248-6263. https://doi.org/10.3168/jds 2012-5790.

Overton, T. R., and M. R. Waldron. 2004. Nutritional management of transition dairy cows: strategies to optimize metabolic health. J. Dairy Sci. 87:E105-E119. https://doi.org/10.3168/jds.S0022 -0302(04)70066-1.

Penagaricano, F., A. H. Souza, P. D. Carvalho, A. M. Driver, R. Gambra, J. Kropp, K. S. Hackbart, D. Luchini, R. D. Shaver, M. C. Wiltbank, and H. Khatib. 2013. Effect of maternal methionine supplementation on the transcriptome of bovine preimplantation embryos. PLoS One 8:e72302. https://doi.org/10.1371/journal .pone.0072302.

Reinhardt, T. A., J. D. Lippolis, B. J. McCluskey, J. P. Goff, and R. L. Horst. 2011. Prevalence of subclinical hypocalcemia in dairy herds. Vet. J. 188:122-124. https://doi.org/10.1016/j.tvjl.2010.03.025.

Richards, D. F. 2011. Strategies to decrease incidence of fatty liver in dairy cows. PhD Thesis, Department of Animal Sciences, University of Illinois, Urbana.

Roche, J. F., D. Mackey, and M. Diskin. 2000. Reproductive management of postpartum cows. Anim. Reprod. Sci. 60-61:703-712. https://doi.org/10.1016/S0378-4320(00)00107-X.

Roche, J. R., A. W. Bell, T. R. Overton, and J. J. Loor. 2013. Nutritional management of the transition cow in the 21st century - A 
paradigm shift in thinking. Anim. Prod. Sci. 53:1000-1023. https: //doi.org/10.1071/AN12293.

Rukkwamsuk, T., T. Wensing, and M. J. Geelen. 1998. Effect of overfeeding during the dry period on regulation of adipose tissue metabolism in dairy cows during the periparturient period. J. Dairy Sci. 81:2904-2911. https://doi.org/10.3168/jds.S0022 -0302(98)75851-5.

Ryan, K. T., A. R. Guadagnin, K. M. Glosson, S. S. Bascom, A. A. Rowson, A. J. Steelman, and F. C. Cardoso. 2020. Increased dietary calcium inclusion in fully acidified prepartum diets improved postpartum uterine health and fertility when fed to Holstein cows. Theriogenology 142:338-347. https://doi.org/10.1016/ j.theriogenology.2019.10.014.

Santos, J. E. P., H. M. Rutigliano, and M. F. Sa Filho. 2009. Risk factors for resumption of postpartum estrous cycles and embryonic survival in lactating dairy cows. Anim. Reprod. Sci. 110:207-221. https://doi.org/10.1016/j.anireprosci.2008.01.014.

Santos, J. E. P., I. J. Lean, H. Golder, and E. Block. 2019. Meta-analysis of the effects of prepartum dietary cation-anion difference on performance and health of dairy cows. J. Dairy Sci. 102:2134-2154. https://doi.org/10.3168/jds.2018-14628.

Sheldon, I. M., G. S. Lewis, S. LeBlanc, and R. O. Gilbert. 2006. Defining postpartum uterine disease in cattle. Theriogenology 65:1516-1530. https://doi.org/10.1016/j.theriogenology.2005.08 .021 .

Sheldon, I. M., D. E. Noakes, and H. Dobson. 2002a. Effect of the regressing corpus luteum of pregnancy on ovarian folliculogenesis after parturition in cattle. Biol. Reprod. 66:266-271. https://doi .org/10.1095/biolreprod66.2.266.

Sheldon, I. M., D. E. Noakes, A. N. Rycroft, D. U. Pfeiffer, and H. Dobson. 2002b. Influence of uterine bacterial contamination after parturition on ovarian dominant follicle selection and follicle growth and function in cattle. Reproduction 123:837-845.

Silva-del-Rio, N., P. M. Fricke, and R. R. Grummer. 2010. Effects of twin pregnancy and dry period strategy on milk production, energy balance, and metabolic profile in dairy cows. J. Anim. Sci. 88:1048-1060. https://doi.org/10.2527/jas.2009-2206.

Skenandore, C. S., D. A. Velasco-Acosta, Z. Zhou, M. I. Rivelli, M. N. Correa, D. Luchini, and F. C. Cardoso. 2017. Effects of rumenprotected methionine and choline supplementation on vaginal discharge and uterine cytology of Holstein cows. Int. J. Vet. Sci. Med. 5:1-7. https://doi.org/10.1016/j.ijvsm.2017.05.001.
Stella, S. L., D. A. Velasco-Acosta, C. Skenandore, Z. Zhou, A. Steelman, D. Luchini, and F. C. Cardoso. 2018. Improved uterine immune mediators in Holstein cows supplemented with rumen-protected methionine and discovery of neutrophil extracellular traps (NET). Theriogenology 114:116-125. https://doi.org/10.1016/j .theriogenology.2018.03.033.

Toledo, M. Z., G. M. Baez, A. Garcia-Guerra, N. E. Lobos, J. N. Guenther, E. Trevisol, D. Luchini, R. D. Shaver, and M. C. Wiltbank. 2017. Effect of feeding rumen-protected methionine on productive and reproductive performance of dairy cows. PLoS One 12:e0189117. https://doi.org/10.1371/journal.pone.0189117.

Vernon, R. G. 2005. Lipid metabolism during lactation: A review of adipose tissue-liver interactions and the development of fatty liver. J. Dairy Res. 72:460-469. https://doi.org/10.1017/ S0022029905001299.

Vickers, L. A., D. M. Weary, D. M. Veira, and M. A. G. von Keyserlingk. 2013. Feeding a higher forage diet prepartum decreases incidences of subclinical ketosis in transition dairy cows. J. Anim. Sci. 91:886-894. https://doi.org/10.2527/jas.2011-4349.

Whitaker, D. A., E. J. Smith, G. O. da Rosa, and J. M. Kelly. 1993. Some effects of nutrition and management on the fertility of dairy cattle. Vet. Rec. 133:61-64. https://doi.org/10.1136/vr.133.3.61.

Winkelman, L. A., T. H. Elsasser, and C. K. Reynolds. 2008. Limitfeeding a high-energy diet to meet energy requirements in the dry period alters plasma metabolite concentrations but does not affect intake or milk production in early lactation. J. Dairy Sci. 91:10671079. https://doi.org/10.3168/jds.2007-0434.

Wu, G., F. W. Bazer, M. C. Satterfield, X. Li, X. Wang, G. A. Johnson, R. C. Burghardt, Z. Dai, J. Wang, and Z. Wu. 2013. Impacts of arginine nutrition on embryonic and fetal development in mammals. Amino Acids 45:241-256. https://doi.org/10.1007/s00726 $-013-1515-z$

Zebeli, Q., and B. U. Metzler-Zebeli. 2012. Interplay between rumen digestive disorders and diet-induced inflammation. Res. Vet. Sci. 93:1099-1108. https://doi.org/10.1016/j.rvsc.2012.02.004.

\section{ORCIDS}

F. C. Cardoso $\odot$ https://orcid.org/0000-0003-1025-3231

K. F. Kalscheur @ https://orcid.org/0000-0002-5290-3602

J. K. Drackley ๑ https://orcid.org/0000-0002-4560-5594 